\title{
A Review on the Catalytic Decomposition of NO by Perovskite-Type Oxides
}

\author{
Qiuwan Shen (D), Shuangshuang Dong, Shian Li *(D), Guogang Yang and Xinxiang Pan
}

Marine Engineering College, Dalian Maritime University, Dalian 116000, China; shenqiuwan@dlmu.edu.cn (Q.S.); dss2020@dlmu.edu.cn (S.D.); yanggg@dlmu.edu.cn (G.Y.); panxx@dlmu.edu.cn (X.P.)

* Correspondence: lishian@dlmu.edu.cn

check for updates

Citation: Shen, Q.; Dong, S.; Li, S.; Yang, G.; Pan, X. A Review on the Catalytic Decomposition of NO by Perovskite-Type Oxides. Catalysts 2021, 11, 622. https://doi.org/ $10.3390 /$ catal11050622

Academic Editor:

Hamidreza Arandiyan

Received: 12 April 2021

Accepted: 10 May 2021

Published: 12 May 2021

Publisher's Note: MDPI stays neutral with regard to jurisdictional claims in published maps and institutional affiliations.

Copyright: (c) 2021 by the authors. Licensee MDPI, Basel, Switzerland. This article is an open access article distributed under the terms and conditions of the Creative Commons Attribution (CC BY) license (https:// creativecommons.org/licenses/by/ $4.0 /)$.

\begin{abstract}
Direct catalytic decomposition of NO has the advantages of being a simple process, producing no secondary pollution, and being good for the economy, which has attracted extensive research in recent years. Perovskite-type mixed oxides, with an $\mathrm{ABO}_{3}$ or $\mathrm{A}_{2} \mathrm{BO}_{4}$ structure, are promising materials as catalysts for NO decomposition due to their low cost, high thermal stability, and, of course, their good catalytic performances. In this review, the influence factors, such as A-site substitution, B-site substitution and reaction conditions on the catalytic performance of catalysts have been expounded. The reaction mechanisms of direct NO decomposition are also discussed. Finally, major conclusions are drawn and some research challenges are highlighted.
\end{abstract}

Keywords: NO direct decomposition; perovskite-type oxides; A-site substitution; B-site substitution

\section{Introduction}

$\mathrm{NO}_{x}$ is one of the main pollutants that can seriously endanger human health and the ecological environment. It is the main pollutant in the formation of acid rain: $\mathrm{NO}_{x}$ and $\mathrm{HC}$ react chemically under the action of sunlight to generate photochemical smog. $\mathrm{NO}_{x}$ can destroy the ozone layer causing global climate change, therefore, the harm caused by $\mathrm{NO}_{x}$ cannot be ignored [1,2].

Direct catalytic decomposition of NO has the advantages of being a simple process, producing no secondary pollution, and being good for the economy, which has attracted extensive research in recent years $[3,4]$.

$$
\begin{gathered}
2 \mathrm{NO}_{(\mathrm{g})}=\mathrm{N}_{2(\mathrm{~g})}+\mathrm{O}_{2(\mathrm{~g})} \\
\Delta \mathrm{H}_{\mathrm{f}(298 \mathrm{~K})}^{0}=90.2 \mathrm{~kJ} \cdot \mathrm{mol}^{-1}
\end{gathered}
$$

As can be seen from the above equation, the reaction is thermodynamically favorable. This decomposition reaction has highly negative Gibbs free energy $(\Delta \mathrm{rGm}=-86 \mathrm{~kJ} / \mathrm{mol})$, and the tendency of $\mathrm{NO}$ decomposition to generate $\mathrm{N}_{2}$ and $\mathrm{O}_{2}$ is large. Although it is thermodynamically feasible, the reaction needs to overcome the high activation energy of the reaction $\left(\sim 335 \mathrm{~kJ} / \mathrm{mol}^{-1}\right)[5,6]$. Accordingly, NO can decompose smoothly under a catalyst and certain temperature conditions, and the development of greatly active and stable catalysts have always been a popular research direction and challenging task. The process is free of secondary pollution and does not require a reducing agent, which largely reduces the operating costs.

Most of the studies of NO direct catalytic decomposition catalysts focus on six types of catalysts, including noble metals, metal oxides, perovskite-type mixed oxides, ion-exchange ZSM-5 type molecular sieves, multi-compounds, and hydrotalcite type materials [6]. Although some noble metals and metal oxides have high activity, there is catalyst poisoning during NO decomposition. Besides, metal oxide catalysts are also very sensitive to $\mathrm{SO}_{2}$. When $\mathrm{SO}_{2}$ is present it is easy to generate sulfate, which will poison and deactivate the 
catalyst. Noble metals are expensive and resources are scarce, whereas perovskite-type mixed oxides have the advantages of good thermal stability and stable oxygen vacancies on the surface. Therefore, the removal of NO by perovskite-type composite oxides has become one of the research hotspots of catalytic decomposition denitrification technology. The research progress and the current state of direct catalytic decomposition of NO by perovskite-type oxides will be reviewed, and the future developmental direction will be discussed.

\section{Mechanism of NO Decomposition on Perovskite-Type Oxides}

The perovskite-type oxide structure is $\mathrm{ABO}_{3}$, which is a cubic crystal with A-site or B-site cations as nodes, and is consistent with the perovskite $\left(\mathrm{CaTiO}_{3}\right)$ structure. In general, the metal ions at position A are mostly rare earth metal, alkaline earth metal, and lanthanide metal, which are located at the center of the structure and coordinate with the surrounding 12 oxygen atoms. The metal ions at position B are mostly transition metal ions, which are located in the body center of the octahedral structure and coordinate with the surrounding six oxygen atoms [7]. Among them, metal ion B determines the catalytic performance of the catalyst, and the role of metal ion $\mathrm{A}$ is mainly to stabilize the crystal structure. The ideal crystal structure of $\mathrm{ABO}_{3}$ perovskite is shown in Figure 1.

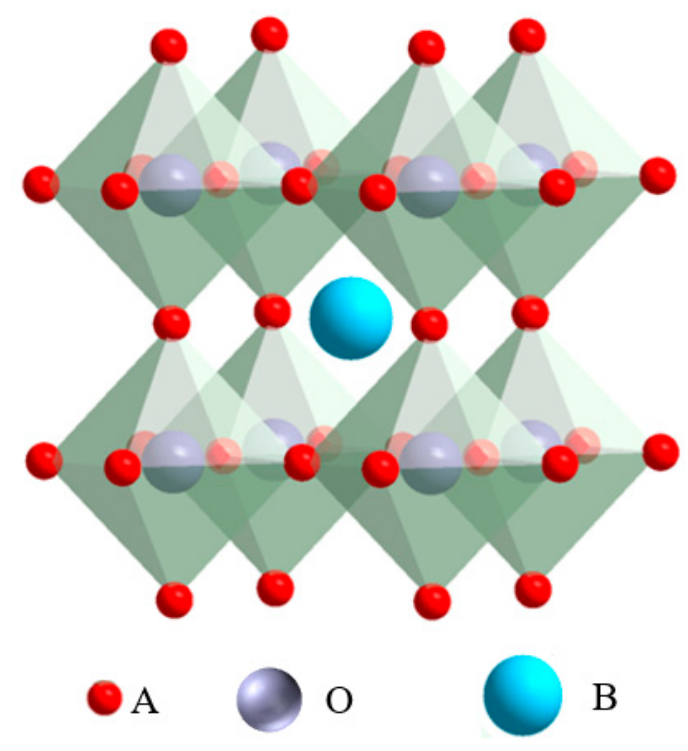

Figure 1. A schematic of the ideal $\mathrm{ABO}_{3}$ perovskite unit cell.

There are defects in perovskite oxide crystals like most crystals. According to the electric neutral principle, $\mathrm{ABO}_{3}$ can be composed of three kinds: $\mathrm{A}^{+1} \mathrm{~B}^{+5} \mathrm{O}_{3}, \mathrm{~A}^{+2} \mathrm{~B}^{+4} \mathrm{O}_{3}$, $\mathrm{A}^{+3} \mathrm{~B}^{+3} \mathrm{O}_{3}$. In the perovskite structure, the larger radius of the $\mathrm{A}$ ion can be partially or completely lost, so A-site ion defects are common. The B-site ions have a relatively large charge and small ionic radius. From a thermodynamic point of view, the B-site is unfavorable. There are several ways to generate ionic defects:

(1) Substitution of high valence ions (rare earth elements) with low valence ions $\mathrm{A}^{\prime}$ (generally alkaline earth metals). According to the principle of electroneutrality, high valence B-site ions and oxygen vacancies can be generated;

(2) Substitution of low valence ion $\mathrm{A}$ with high valence ion $\mathrm{A}^{\prime}$ can generate low $\mathrm{B}$ valence ion and A vacancy;

(3) Substitution of high valence B ions with low valence $B^{\prime}$ ions.

The changes and catalytic reactions of various valence states and oxygen defects of $A$ and B above can generally occur simultaneously.

Zhu et al. [8] believed that oxygen vacancy played a crucial role in the decomposition of $\mathrm{NO}$, and the active center of NO decomposition was composed of oxygen vacancy and 
transition metal with low oxidation state. A large number of oxygen vacancies generally exist in the perovskite-type oxide structure, which provides space and convenience for the adsorption and decomposition of NO. The adsorbed NO obtains an electron from the transition metal with a lower oxidation state. Meanwhile, it is activated by the electron to participate in the reaction.

For the decomposition mechanism of NO on perovskite-type catalysts, Shin et al. [9] thought that, at first, two molecules of $\mathrm{NO}$ attached on the $\mathrm{Fe}^{3+}$ with some oxygen vacancies, and then the NO molecules coordinated with the iron ions. At the same time, the iron atoms changed their valence state from $\mathrm{Fe}^{3+}$ to $\mathrm{Fe}^{4+}$, giving one electron per one coordinating $\mathrm{NO}$ molecule. The $\mathrm{N}-\mathrm{O}$ bond in the coordinating nitrosyl ion $\left(\mathrm{NO}^{-}\right)$is so weak that cleavage of the $\mathrm{N}-\mathrm{O}$ bond may occur, yielding a free molecule of $\mathrm{N}_{2}$. Subsequently, the thermal energy supplied to the reaction system at a certain temperature will cause the release of the oxygen atoms from the $\mathrm{Fe}^{4+}$. Then, an oxygen molecule will be also isolated from the reaction system, and again the $\mathrm{Fe}^{3+}$, with accompanying oxygen vacancies, are regenerated, and the reaction mechanism is shown in Figure 2. This scheme is thought to be credible for the thermal decomposition of $\mathrm{NO}$ over an oxygen-deficient perovskite $\mathrm{SrFeO}_{3-x}$ because the unique lattice of $\mathrm{SrFeO}_{3-x}$ itself easily stabilizes an unusual valence state of +4 for the irons, and it also tends to accommodate appreciable oxygen defects with increasing temperature.

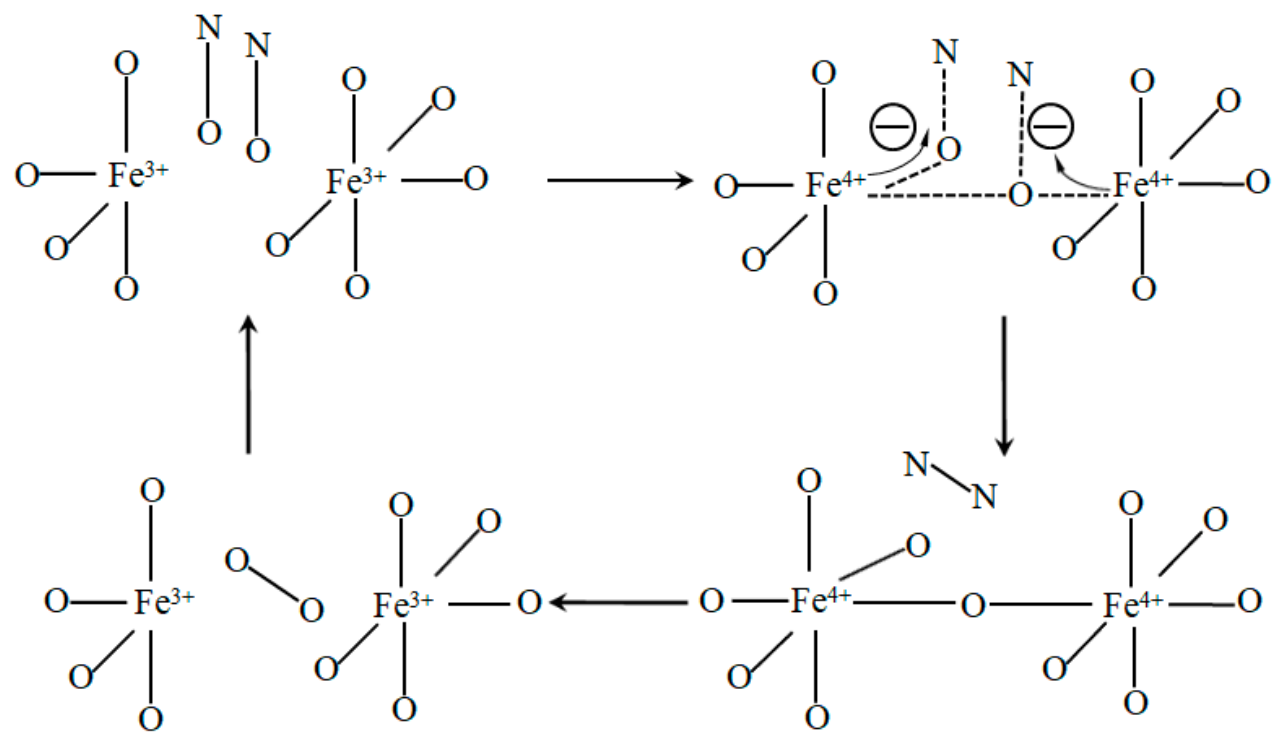

Figure 2. A possible mechanism of NO decomposition on the perovskite-type catalyst. Adapted with permission from [9], 2021, Elsevier.

Teraoka et al. [10] proposed the reaction mechanism of direct decomposition of NO on perovskite oxides. A pair of NO molecules was first adsorbed onto the adjacent oxygen vacancies on the surface of the catalyst, and then the two adjacent $\mathrm{N}-\mathrm{O}$ bonds were dissociated to form a free $\mathrm{N}_{2}$ molecule, and finally released into the gas phase, as shown in Figure 3. Since the adsorption of the second NO molecule at the paired position is a rate-determined step, the important characteristics of this reaction are NO adsorption capacity and oxygen ion vacancy. Besides, the cation activity of the B-site greatly affects the catalytic activity, because B-site ions are adjacent to oxygen anions, and $\mathrm{O}_{2}$ desorption plays an important role in the regeneration of cation vacancies. 


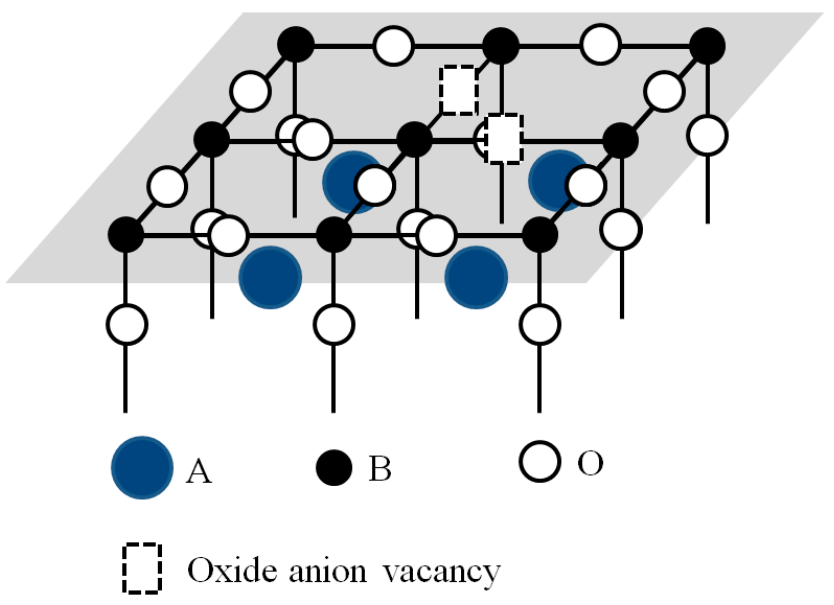

$\mathrm{NO}+\left([\mathrm{]}] \cdot[\mathrm{]}) \stackrel{\mathrm{K}_{1}}{\underset{\mathrm{K}_{\cdot 1}}{\rightleftharpoons}}\left(\left[\begin{array}{l}\mathrm{N} \\ \mathrm{O}] \cdot[\mathrm{]}]\end{array}\right)\right.\right.$

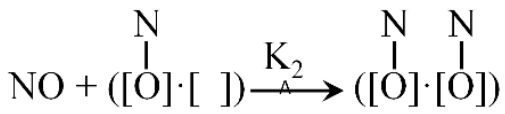

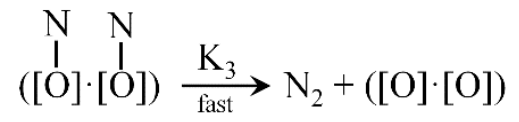

$([\mathrm{O}] \cdot[\mathrm{O}]) \underset{\mathrm{K}_{4}}{\stackrel{\mathrm{K}_{4}}{\rightleftharpoons}} \mathrm{O}_{2}+([\mathrm{]}] \cdot[\mathrm{]})$

Figure 3. A possible reaction mechanism for the direct decomposition reaction of NO on perovskitetype oxides. Adapted with permission from [10], 2021, Royal Society of Chemistry.

Zhu et al. [11] explored the decomposition mechanism of $\mathrm{NO}$ on perovskite-like oxides by studying the $\mathrm{O}_{2}$-TPD experiment and $\mathrm{NO}$ decomposition activity. The $\mathrm{NO}$ was first absorbed and dissociated into $\mathrm{N}_{2}$ and atomic oxygen, which then reacted with another $\mathrm{NO}$ to form the adsorbed $\mathrm{NO}_{2}$ and, after that, the adsorbed $\mathrm{NO}_{2}$ desorbed and dissociated into $\mathrm{NO}$ and $\mathrm{O}_{2}$. In this process, $\mathrm{NO}_{2}$ acted as an intermediate of $\mathrm{O}_{2}$ formation. The results showed that the decomposition of $\mathrm{NO}$ on perovskite-like oxides was carried out in a cycle manner, in which the cycle (generation and decomposition) of $\mathrm{NO}_{2}$ played an important role in the reaction and was closely related to the activity.

(a) $\mathrm{NO}_{2}$ is mainly generated on the surface of the catalyst:

$$
\mathrm{NO}_{(\mathrm{g})}+\mathrm{O}_{(\mathrm{a})}=\mathrm{NO}_{2(\mathrm{a})}
$$

(b) Oxygen desorption step:

$$
\mathrm{O}_{(\mathrm{a})}+\mathrm{O}_{(\mathrm{a})}=\mathrm{O}_{2(\mathrm{~g})}
$$

$\mathrm{NO}_{2}$ dissociation reaction $\left(2 \mathrm{NO}_{2}=2 \mathrm{NO}+\mathrm{O}_{2}\right)$ is an important step in the process of $\mathrm{NO}$ decomposition as the catalytic activity of $\mathrm{NO}$ decomposition on perovskite-like oxides only occurs at high temperatures. The cyclic decomposition mechanism of NO on perovskite-like oxides with $\mathrm{NO}_{2}$ as intermediate species is shown in Figure 4. 


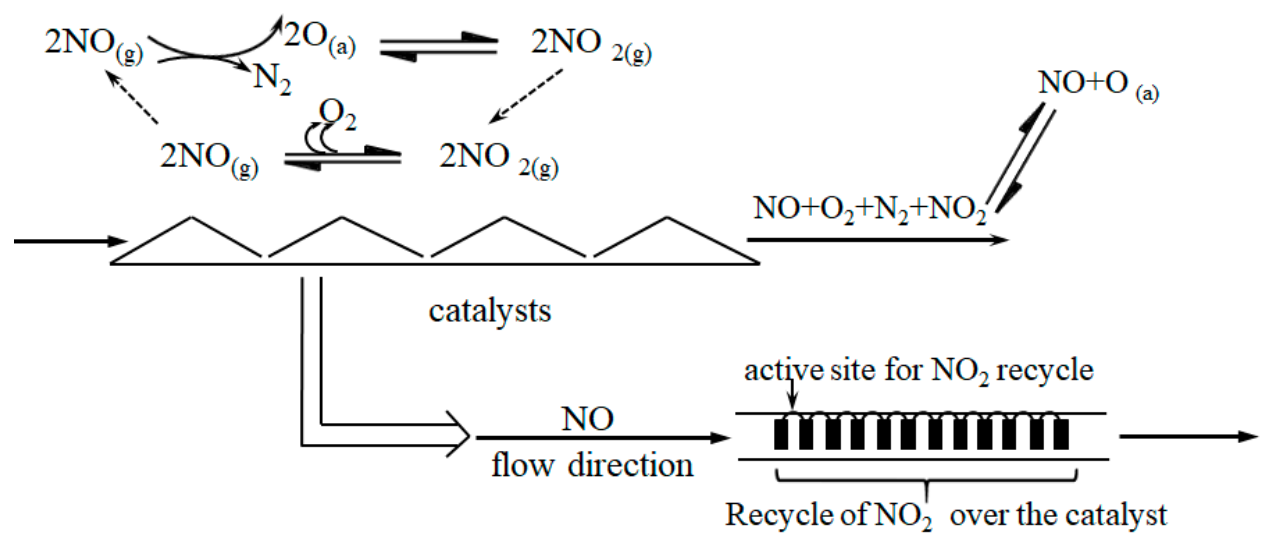

Figure 4. The mechanism of cyclic decomposition of $\mathrm{NO}$ on perovskite-like oxides with $\mathrm{NO}_{2}$ as an intermediate species.

A large number of oxygen vacancies or oxygen excess in perovskite-like oxides favor the decomposition of $\mathrm{NO} ; \mathrm{NdSrCu}_{1-x} \mathrm{Co}_{x} \mathrm{O}_{4-\delta}$ has a higher density of oxygen vacancies and a stronger $\mathrm{Cu}^{3+} / \mathrm{Cu}^{2+}$ redox capacity, which is more likely to activate $\mathrm{NO}$ and is responsible for the enhancement of catalytic performance [12-14].

Perovskite composite oxides have good thermal stability and oxygen defects, so they have been considered promising catalysts for catalytic NO decomposition [15]. On the one hand, oxygen vacancies provide vacancies for $\mathrm{NO}$ adsorption, while on the other, electrons generated in the structure can activate NO. The existence of oxygen vacancies and redox properties of $\mathrm{B}$-site ions are two main factors affecting $\mathrm{NO}$ adsorption and activation, which play an important role in the reaction process. In recent years, perovskite catalysts have become a research hotspot in the field of catalytic decomposition of NO due to their good direct decomposition performance [16,17].

It is generally believed that the catalytic activity mainly depends on the B-site ions, while the A-site ions mainly play a role in stabilizing the crystal structure. However, the substitution of A-site atoms by other valence atoms can change the valence of B-site ions and the content of oxygen vacancies in the structure. For example, the content of $\mathrm{Fe}^{2+}$ and $\mathrm{Fe}^{3+}$ ions and oxygen vacancy $(\delta)$ in $\mathrm{La}_{1-x} \mathrm{Sr}_{x} \mathrm{FeO}_{3+\delta}$ can be changed by the substitution of $\mathrm{Sr}^{2+}$ with $\mathrm{La}^{3+}$. Due to the unique structural characteristics of perovskite, the original crystal structure of perovskite will not be destroyed by doping different valence metal ions at A- or B-site within the allowable range of the tolerance factor. Therefore, the decomposition activity of $\mathrm{NO}$ can be improved by doping different metal ions [18].

\section{Effect of A-Site Substitution}

The A-site ions of perovskite are larger radius ions. The ions on the A-site will indirectly promote catalytic activity. When the A-site ions are substituted, there are more defects produced and they will affect the electronic state of the B-site ions [19]. Meanwhile, A-site doping can change the oxidation state of B-site ions, and B-site ions are easily reduced to highly disperse metal centers [20-22]. A- and B-sites play different roles in the reaction process. B-site mainly affects the temperature range of the reaction, and A-site mainly affects the selectivity of the reaction. Higher lattice oxygen mobility and lower active oxygen adsorption are also the key factors to determining catalyst activity. Divalent alkaline earth ions are often used to partially replace the A-site ions to increase the alkalinity and generate anion oxide vacancies through charge compensation.

\subsection{Effect of Dopants}

Zhu et al. [23] found that if external A-site cations could not change the oxidation state of B-site cations, the effect of A-site substitution on catalytic performance was indirect, i.e., by changing the oxidation state of B-site cations or generating oxygen vacancies. This 
indicates that although $\mathrm{Sr}^{2+}$ had no activity on the decomposition of $\mathrm{NO}$, it could affect the reaction rate by changing the average oxidation of B-site cations.

Yasuda et al. [24] studied the effect of $\mathrm{Sr}$ substitution on NO decomposition by $\mathrm{La}_{2-x} \mathrm{Sr}_{x} \mathrm{CuO}_{4}$ and demonstrated that the substitution influence was caused by changing the average oxidation state of $\mathrm{Cu}$. The catalytic activity is closely related to the average oxidation state of $\mathrm{Cu}$, and its value is closely related to the amount of $\mathrm{Sr}^{2+}$ substitution. He et al. [25] prepared $\mathrm{La}_{1-x} \mathrm{Sr}_{x} \mathrm{FeO}_{3}$ perovskite composite oxides. After La was partially replaced by $\mathrm{Sr}$, more oxygen vacancies were generated and the catalytic performance was improved. In recent years, barium has been considered as a promising A-site ion for perovskite catalysts because it not only has a low oxidation state $(+2)$, it also has the potential to capture $\mathrm{NO}_{x}$, thus ensuring the supply of $\mathrm{NO}_{x}$ in the reaction.

An A-site cation does not necessarily have no catalytic activity, but as long as the A-site cation has a variable oxidation state, it can indeed participate in the reaction process. Notably, Ce enters the structural framework of $\mathrm{La}_{1-x} \mathrm{Ce}_{x} \mathrm{SrNiO}_{4}$ up to $30 \%(x=0.3)$, which is much higher than the reported $\mathrm{ABO}_{3}$ structure of perovskite-type oxides $\left(\mathrm{La}_{1-x} \mathrm{~A}^{\prime}{ }_{x} \mathrm{BO}_{3}\right.$ is usually below 10\%) [26-28]. Belessi et al. [29] found that the substitution of $\mathrm{Ce}$ in $\mathrm{La}_{0.5} \mathrm{Sr}_{x} \mathrm{Ce}_{y} \mathrm{FeO}_{z}$ was very difficult. No perovskite oxide containing Ce was detected in this system.

Zhu et al. [30] added $\mathrm{Sr}$ in $\mathrm{La}_{2} \mathrm{CuO}_{4}$ and the $\mathrm{NO}$ decomposition conversion rate was low $\left(34.3 \%, \mathrm{t}=850{ }^{\circ} \mathrm{C}\right)$. For a $\mathrm{La}_{2-x} \mathrm{Th}_{x} \mathrm{CuO}_{4}(0 \leq x \leq 0.4)$ catalyst, $\mathrm{Zhu}$ et al. [22] showed that $\mathrm{Cu}^{+}$was easily oxidized in the redox cycle of $\mathrm{Cu}^{+} \leftrightarrow \mathrm{Cu}^{2+}$, so that the active adsorption rate of $\mathrm{Cu}^{+}$at $850{ }^{\circ} \mathrm{C}$ was the highest, reaching about $42 \%$. Chen et al. [31] prepared a $\mathrm{La}_{1.6} \mathrm{Ba}_{0.4} \mathrm{NiO}_{4}-x \% \mathrm{BaO}(x=0,5,10,15,20,25,30)$ catalytic by heating a mixture of $\mathrm{Ba}\left(\mathrm{NO}_{3}\right)_{2}$ and $\mathrm{La}_{1.6} \mathrm{Ba}_{0.4} \mathrm{NiO}_{4}$, and evaluated their catalytic performance. The results showed that the activity of the $\mathrm{La}_{1.6} \mathrm{Ba}_{0.4} \mathrm{NiO}_{4}-x \% \mathrm{BaO}$ catalysts increased with the increase of the amount of $\mathrm{BaO}$.

Iwakuni et al. [32] showed that $\mathrm{La}_{1.6} \mathrm{Ba}_{0.4} \mathrm{NiO}_{4}-20 \% \mathrm{BaO}$ had the highest activity, and the yield of nitrogen increased from $51.7 \%$ to $98.8 \%$ at $600-850{ }^{\circ} \mathrm{C}$. The results showed that the addition of $\mathrm{BaO}$ increased the number of oxygen vacancies and the mobility of lattice oxygen. Besides, $\mathrm{BaO}$ played an important role in the transport and storage of $\mathrm{NO}$ and facilitated the reconstruction of active centers. Zhang et al. [33] prepared a series of perovskite-type $\mathrm{La}_{1-x} \mathrm{Ce}_{x} \mathrm{FeO}_{3}(x=0-0.5)$ nanocomposites by sol-gel method and studied the effect of Ce doping ratio on NO conversion rate. When the doping amount is 0.3 , the conversion of $\mathrm{NO}$ can reach $80 \%$ at low temperatures.

Li et al. [34] prepared a series of perovskite $\mathrm{La}_{1-x} \mathrm{Ce}_{x} \mathrm{MnO}_{3}(x=0-0.2)$ nanocomposites by sol-gel method and studied the effect of a $\mathrm{Ce}^{4+}$ doping ratio on $\mathrm{NO}$ conversion. The results showed that the catalytic activity of active perovskite species was improved by adding the appropriate amount of $\mathrm{Ce}^{4+}$ to the $\mathrm{La}^{3+}$ site.

Dong et al. [35] prepared a series of $\mathrm{La}_{0.7} \mathrm{Sr}_{0.3} \mathrm{MnO}$ perovskite catalysts by the sol-gel method under different synthesis conditions. The results showed that the initial $\mathrm{pH}$ value of the precursor solution had a great influence on the shape and size of the catalyst, which directly related to the $\mathrm{NO}_{x}$ storage capacity of the catalyst. Also, the oxidation capacity of the $\mathrm{NO}$ was determined by the amount of excess oxygen in the perovskite.

Gao et al. [36] further found that after a reduction in $\mathrm{H}_{2}\left(\mathrm{H}_{2} / \mathrm{He}=1 / 9\right.$, flow rate: $20 \mathrm{~mL} \cdot \mathrm{min}^{-1}$ ) at $300{ }^{\circ} \mathrm{C}$, the catalytic performance of $\mathrm{La}_{1.867} \mathrm{Th}_{0.100} \mathrm{CuO}_{4}$ was effectively improved, and $91 \% \mathrm{NO}$ conversion (converted to $\mathrm{N}_{2}$ ) was obtained at $650{ }^{\circ} \mathrm{C}$.

In addition, sometimes the substitution of A-site cations changes the crystalline phase from an ordered structure to a disordered structure, thus affecting the catalytic performance. Shin et al. [25] reported that $\mathrm{Ca}_{2} \mathrm{Fe}_{2} \mathrm{O}_{5+\delta}$ with ordered oxygen vacancies had no activity to decompose $\mathrm{NO}$ even at $900{ }^{\circ} \mathrm{C}$, while $\mathrm{Sr}$ was substituted for $\mathrm{Ca}$, i.e., $\mathrm{Sr}_{2} \mathrm{Fe}_{2} \mathrm{O}_{5+\delta}$ with disordered oxygen vacancies. Besides, a $\mathrm{Ce}^{3+/ 4+}$ partial substitution of site ions facilitated the regeneration of the active site due to the redox properties of the cerium ion, which can release oxygen adsorbed on the oxide anion defects. This redox effect is more obvious in $\mathrm{K}_{2} \mathrm{NiF}_{4}$ perovskite oxides deposited alternately between the $\mathrm{ABO}_{3}$ layer and $\mathrm{AO}$ layer, but 
not in $\mathrm{ABO}_{3}$ type oxides. Because the cavity space of the $\mathrm{K}_{2} \mathrm{NiF}_{4}$ lattice is larger than that of the $\mathrm{ABO}_{3}$ lattice, larger $\mathrm{Ce}$ ions can replace some A-site ions. Besides, $\mathrm{Sr}^{2+}$ can compensate charge at the B-site.

\subsection{Effect of Coexisting Gases}

In the absence of coexisting gases, the $\mathrm{N}_{2}$ yield of the $\mathrm{NO}$ decomposition of a perovskite catalyst was over $70 \%$. However, the reaction was strongly inhibited by the presence of $\mathrm{O}_{2}$ and $\mathrm{CO}_{2} \cdot \mathrm{Ba}_{0.8} \mathrm{La}_{0.2} \mathrm{Mn}_{0.8} \mathrm{Mg}_{0.2} \mathrm{O}_{3}$, the most active catalyst among the $\mathrm{ABO}_{3}$-type oxides, gave about $80 \% \mathrm{~N}_{2}$ yield for $\mathrm{NO}$ decomposition at $850{ }^{\circ} \mathrm{C}$ and in the absence of coexisting gases. In contrast, under the presence of $5 \% \mathrm{CO}_{2}$, the concentration was reduced to less than $20 \%$ due to the dissociative adsorption of $\mathrm{CO}_{2}$ on the catalyst surface and the strong adsorption of the resulting $\mathrm{CO}$ on the active site [37]. $\mathrm{CO}_{2}$ poisoning has an enormous negative impact on the catalytic performance of $\mathrm{NO}$ decomposition. In addition, when the catalyst was heated at $700{ }^{\circ} \mathrm{C}$, the adsorbed $\mathrm{CO}$ molecules were desorbed from the surface, without desorption at a lower temperature of $600{ }^{\circ} \mathrm{C}$.

For $\mathrm{La}_{0.8} \mathrm{Sr}_{0.2} \mathrm{CoO}_{3}, \mathrm{CO}_{2}$ inhibited $\mathrm{NO}$ decomposition through carbonate formation, which is different from the poisoning mechanism observed in $\mathrm{Ba}_{0.8} \mathrm{La}_{0.2} \mathrm{Mn}_{0.8} \mathrm{Mg}_{0.2} \mathrm{O}_{3}$, although they are similar perovskite oxides [38]. A $\mathrm{La}_{0.8} \mathrm{Sr}_{0.2} \mathrm{CoO}_{3}$ catalyst needs to be heated above $750{ }^{\circ} \mathrm{C}$ to decompose carbonate. Therefore, to effectively decompose NO in the presence of $\mathrm{CO}_{2}$, a new and advanced catalyst is needed, which can inhibit the reaction with $\mathrm{CO}_{2}$ and limit the adsorption of $\mathrm{CO}_{2}$.

\section{Effect of B-Site Substitution}

The substitution effect of B-site cations is much more complex than that of A-site cations. Because B-site cations can not only change their oxidation state, but also an important part of the active site.

\subsection{Effect of Dopants}

$\mathrm{LaMO}_{3}$ lanthanide is a common B-site substituted perovskite system. It is generally believed that $\mathrm{La}^{3+}$ mainly fixes the crystal structure of the catalyst, and the main catalytic effect is controlled by B-site ions. Yokoi and Uchida [39] studied the reactivity of different B-site cations to $\mathrm{NO}$ decomposition directly in $\mathrm{LaMO}_{3}(\mathrm{M}=\mathrm{Cr}, \mathrm{Mn}, \mathrm{Fe}, \mathrm{Co}$, and Ni).

Figure 5 compares the $\mathrm{NO}$ decomposition catalytic activity of some $\mathrm{LaMO}_{3}$-based perovskite [30-43].

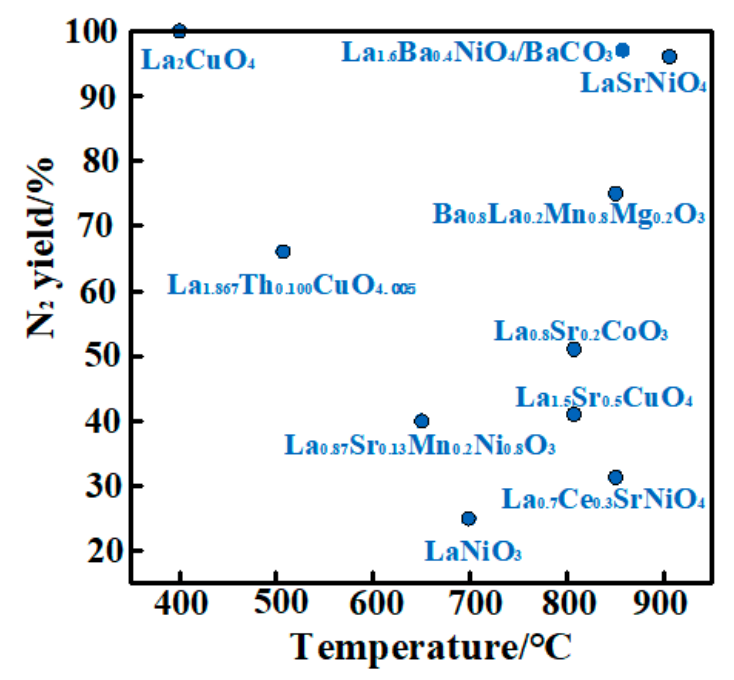

Figure 5. NO decomposition catalytic activity of some $\mathrm{LaMO}_{3}$-based perovskite.

For $\mathrm{BaMnO}_{3}$-based perovskite oxides, Iwakuni et al. [37] studied the effect of dopants on NO direct decomposition activity. Goto et al. [44] investigated the effect of B-site 
substitution on the NO decomposition activity of $\mathrm{SrFe}_{0.7} \mathrm{M}_{0.3} \mathrm{O}_{3}$ activity in the order of $\mathrm{Mg}>\mathrm{Sn}>\mathrm{Ni}>\mathrm{Ce}>\mathrm{Zr}$. The NO decomposition activity was $\mathrm{Mg}>\mathrm{Sn}>\mathrm{Ni}>\mathrm{Ce}>\mathrm{Zr}$. Notably, Kazuya [45] found that $\mathrm{Ba}_{3} \mathrm{Y}_{3.4} \mathrm{Sc}_{0.6} \mathrm{O}_{9}$ with a perovskite structure composed of alkaline earth metals and rare earth ions exhibited high NO decomposition activity in the temperature range of $600-850{ }^{\circ} \mathrm{C}$.

The application of lanthanide-free perovskite catalysts in NO decomposition reactions has been studied by many researchers. Traditional three-way catalysts (TWCs) in reducing $\mathrm{NO}_{x}, \mathrm{CO}$, and $\mathrm{HC}$ are very effective, considering the need for the development of highefficiency catalyst. Glisenti et al. [46] studied the effect of rare-earth element (typically lanthanum) perovskite oxides on the activity of the catalyst: $\mathrm{Co}$ and $\mathrm{Cu}$ were doped active cations and the results showed that $\mathrm{Co}$ appeared to be active in oxidation, while $\mathrm{Cu}$ was necessary for reduction. Strontium titanates $\left(\mathrm{Sr}_{1-x} \mathrm{~K}_{x} \mathrm{TiO}_{3}, x=0.1-0.5\right)$, partially replaced with potassium, were prepared by the citric acid sol-gel method [47]. The promoting effect of potassium on the formation of oxygen vacancy and surface alkalinity was discussed, in which molecular oxygen or $\left(\mathrm{NO}, \mathrm{NO}_{2}\right)$ was absorbed to form basic surface oxygen species soot oxidation.

Carlotto et al. [48] studied the NO reduction in a CO-NO atmosphere at the $\mathrm{Co}$ and $\mathrm{Cu}$-doped $\mathrm{SrTiO}_{3}$ surface by density function theory. They found that the step to determine the rate is the formation of oxygen vacancy, which is beneficial to the doping of $\mathrm{Cu}$ - and Co. Due to its higher ability to stabilize oxygen vacancy, the catalytic performance of the $\mathrm{Cu}$-doped surface was improved at the same time. While the solubility of $\mathrm{Cu}$ was low in $\mathrm{SrTiO}_{3}, \mathrm{Cu}$-doping is predicted to be particularly effective.

\subsection{Effect of Coexisting Gases}

To improve the oxygen resistance of the catalyst, $\mathrm{Zhu}$ et al. [49] added an appropriate amount of Ce in $\mathrm{LaSrNiO}_{4}$. Among these $\mathrm{La}_{1-x} \mathrm{Ce}_{x} \mathrm{SrNiO}_{4}, \mathrm{La}_{0.7} \mathrm{Ce}_{0.3} \mathrm{SrNiO}_{4}$ showed high direct decomposition activity at $900{ }^{\circ} \mathrm{C}$ even in the presence of $6.0 \% \mathrm{O}_{2}$. At $800{ }^{\circ} \mathrm{C}$, the yield of nitrogen reached about $75 \%$. In the presence of $1.0 \%$ and $4.0 \%$ oxygen, the yield of nitrogen reached $50.5 \%$ and $39.8 \%$, respectively [50]. The results of Zhu et al. [51] showed that the NO decomposition activity of laser crystal could be improved by replacing manganese with nickel. $\mathrm{LaSrMn}_{1-x} \mathrm{Ni}_{x} \mathrm{O}_{4+\delta}(x=0.8)$ had the highest nitrogen yield at about $85 \%$ at $850{ }^{\circ} \mathrm{C}$ and about $75 \%$ even in the presence of $2.5 \%$ oxygen. XPS characterization showed that the stronger the catalyst bonded to oxygen, the lower the catalytic decomposition activity. Ma et al. [52] studied nickel-containing $\mathrm{A}_{2} \mathrm{BO}_{4}$ oxide catalysts. Through research, it was found that these catalysts have excellent catalytic performance at low temperatures, which is very suitable for simultaneous removal of $\mathrm{NO}_{x}$ and diesel soot.

Gao et al. [53] synthesized a special structure of $\mathrm{La}_{2} \mathrm{CuO}_{4}$ nanofibers using singlewalled carbon nanotubes (CNT) as a template. At temperatures above $300{ }^{\circ} \mathrm{C}, 100 \% \mathrm{NO}$ conversion could be obtained without other by-products. Wang et al. [54] combined a $\mathrm{BaBi}_{0.05} \mathrm{Co}_{0.8} \mathrm{Nb}_{0.15} \mathrm{O}_{3-\delta}(\mathrm{BBCN})$ hollow fiber membrane with a nickel silicate hollow sphere catalyst to fabricate a novel bifunctional catalytic peroxide hollow fiber membrane reactor. Using this new catalytic membrane reactor, the oxygen in the NO decomposition reaction system was instantaneously removed, and $\mathrm{NO}$ was completely converted to $\mathrm{N}_{2}$ at low temperatures $\left(675^{\circ} \mathrm{C}\right)$. Dhal et al. [55] applied the solution of combustion synthesis technology to the production of $\mathrm{LaFeO}_{3}$ and improved its $\mathrm{NO}$ purification activity by increasing the specific surface area of $\mathrm{LaFeO}_{3}$ with high exothermic and selfsustaining reactions.

Using these efficient composite materials, combined with the existing knowledge of structure, the catalytic activity of perovskite oxide was analyzed. It is hoped that an efficient perovskite oxide catalyst can be successfully found to remove NO and meet the requirements of a large-scale application.

As can be seen from Table 1, the $\mathrm{BaMnO}_{3}$-based perovskite shows low catalytic activity. Meanwhile, the catalytic activity increased after loading $\mathrm{Pt}$, indicating that the adsorption strength of surface oxygen was weakened by Pt. The adsorption capacity and efficiency of 
oxygen vacancy could be improved by doping $\mathrm{Ba}$ in perovskite catalyst. The difference of the activity between Ce-doped perovskite in the presence of $1 \% \mathrm{O}_{2}$ and the absence of oxygen was very slight, which indicates that the Ce-doped perovskite sample had a strong resistance to oxidation. The direct decomposition capacity of perovskite oxide doped with $\mathrm{Sr}$ was greatly affected by Fe doping. Fe was replaced by a low valence cation in $\mathrm{SrFeO}_{3}$, and a small amount of $\mathrm{Pt}$ was loaded at the same time, which was very effective for a decomposition reaction of NO.

In conclusion, there has been much research done on the doping of a perovskite oxide catalyst with La. The high activity of a perovskite oxide catalyst can be obtained by doping $\mathrm{La}$ and the catalytic performance of the catalyst can be improved by doping $\mathrm{Ba}, \mathrm{Ni}, \mathrm{Ce}$, etc.

Table 1. A summary of the reaction conditions and maximum nitrogen yield of major perovskite catalysts.

\begin{tabular}{|c|c|c|c|}
\hline Catalysts & $\mathrm{N}_{2}$ Yield (\%) & Reaction Conditions & Refs. \\
\hline $\mathrm{La}_{1.4} \mathrm{Sr}_{0.6} \mathrm{NiO}_{4}$ & 80 & $1.0 \% \mathrm{NO}, 1.34 \mathrm{~g} \mathrm{~s} \mathrm{~cm}^{-3}, 850^{\circ} \mathrm{C}$ & [7] \\
\hline $\mathrm{La}_{1.2} \mathrm{Sr}_{0.8} \mathrm{NiO}_{4}$ & 20 & $1.0 \% \mathrm{NO}, 1.34 \mathrm{~g} \mathrm{~s} \mathrm{~cm}^{-3}, 700^{\circ} \mathrm{C}$ & [7] \\
\hline $\mathrm{La}_{1.6} \mathrm{Ba}_{0.4} \mathrm{NiO}_{4}-20 \% \mathrm{BaO}$ & 98.8 & $1.0 \% \mathrm{NO}, 1.2 \mathrm{~g} \mathrm{~s} \mathrm{~cm}^{-3}, 850^{\circ} \mathrm{C}$ & [31] \\
\hline $\mathrm{Ba}_{0.9} \mathrm{La}_{0.1} \mathrm{Mn}_{0.8} \mathrm{La}_{0.2} \mathrm{O}_{3}$ & 74.1 & $1.0 \% \mathrm{NO}, 3.0 \mathrm{~g} \mathrm{~s} \mathrm{~cm}^{-3}, 850{ }^{\circ} \mathrm{C}$ & [32] \\
\hline $\mathrm{Ba}_{0.9} \operatorname{Pr}_{0.1} \mathrm{Mn}_{0.8} \operatorname{Pr}_{0.2} \mathrm{O}_{3}$ & 69.6 & $1.0 \% \mathrm{NO}, 3.0 \mathrm{~g} \mathrm{~s} \mathrm{~cm}^{-3}, 850{ }^{\circ} \mathrm{C}$ & {$[32]$} \\
\hline $\mathrm{Ba}_{0.8} \mathrm{La}_{0.2} \mathrm{Mn}_{0.8} \mathrm{Mg}_{0.2} \mathrm{O}_{3}$ & 75 & $1.0 \% \mathrm{NO}, 3.0 \mathrm{~g} \mathrm{~s} \mathrm{~cm}^{-3}, 850{ }^{\circ} \mathrm{C}$ & [32] \\
\hline $\mathrm{BaMn}_{0.8} \mathrm{Mg}_{0.2} \mathrm{O}_{3}$ & 66.8 & $1.0 \% \mathrm{NO}, 3.0 \mathrm{~g} \mathrm{~s} \mathrm{~cm}^{-3}, 850{ }^{\circ} \mathrm{C}$ & [32] \\
\hline $\mathrm{BaMn}_{0.8} \mathrm{Zr}_{0.2} \mathrm{O}_{3}$ & 51.6 & $1.0 \% \mathrm{NO}, 3.0 \mathrm{~g} \mathrm{~s} \mathrm{~cm}^{-3}, 850{ }^{\circ} \mathrm{C}$ & {$[32]$} \\
\hline $\mathrm{BaMnO}_{3}$ & 16.0 & $1.0 \% \mathrm{NO}, 3.0 \mathrm{~g} \mathrm{~s} \mathrm{~cm}^{-3}, 850{ }^{\circ} \mathrm{C}$ & [32] \\
\hline $\mathrm{SrMn}_{0.8} \mathrm{Mg}_{0.2} \mathrm{O}_{3}$ & 37.8 & $1.0 \% \mathrm{NO}, 3.0 \mathrm{~g} \mathrm{~s} \mathrm{~cm}^{-3}, 850{ }^{\circ} \mathrm{C}$ & [32] \\
\hline $\mathrm{SrMn}_{0.8} \mathrm{Fe}_{0.2} \mathrm{O}_{3}$ & 39.7 & $1.0 \% \mathrm{NO}, 3.0 \mathrm{~g} \mathrm{~s} \mathrm{~cm}^{-3}, 850{ }^{\circ} \mathrm{C}$ & [32] \\
\hline $\mathrm{La}_{1.2} \mathrm{Ba}_{0.8} \mathrm{NiO}_{4}$ & 90 & $4.0 \% \mathrm{NO}, 1.2 \mathrm{~g} \mathrm{~s} \mathrm{~cm}^{-3}, 850{ }^{\circ} \mathrm{C}$ & [41] \\
\hline $\mathrm{La}_{1.2} \mathrm{Ba}_{0.8} \mathrm{NiO}_{4}$ & 76 & $4.0 \% \mathrm{NO}, 0.75 \mathrm{~g} \mathrm{~s} \mathrm{~cm}^{-3}, 850^{\circ} \mathrm{C}$ & [41] \\
\hline $\mathrm{La}_{1.6} \mathrm{Ba}_{0.4} \mathrm{NiO}_{4} / \mathrm{BaCO}_{3}$ & 98 & $4.0 \% \mathrm{NO}, 1.2 \mathrm{~g} \mathrm{~s} \mathrm{~cm}^{-3}, 850^{\circ} \mathrm{C}$ & [41] \\
\hline $\mathrm{La}_{0.87} \mathrm{Sr}_{0.13} \mathrm{Mn}_{0.2} \mathrm{Ni}_{0.8} \mathrm{O}_{3}$ & 40 & $1.0 \% \mathrm{NO}, 1.2 \mathrm{~g} \mathrm{~s} \mathrm{~cm}^{-3}, 650{ }^{\circ} \mathrm{C}$ & [41] \\
\hline $\mathrm{La}_{0.8} \mathrm{Ce}_{0.5} \mathrm{NiO}_{4}$ & 70 & $1.0 \% \mathrm{NO}, 1.2 \mathrm{~g} \mathrm{~s} \mathrm{~cm}^{-3}, 800{ }^{\circ} \mathrm{C}$ & {$[41]$} \\
\hline $\mathrm{La}_{1.867} \mathrm{Th}_{0.1} \mathrm{CuO}_{4.005}$ & 65 & $1.0 \% \mathrm{NO}, 1.33 \mathrm{~g} \mathrm{~s} \mathrm{~cm}^{-3}, 500{ }^{\circ} \mathrm{C}$ & [42] \\
\hline $\mathrm{La}_{1.6} \mathrm{Th}_{0.4} \mathrm{CuO}_{4}$ & 42 & $1.0 \% \mathrm{NO}, 1.33 \mathrm{~g} \mathrm{~s} \mathrm{~cm}^{-3}, 850^{\circ} \mathrm{C}$ & [42] \\
\hline $\mathrm{SrFe}_{0.7} \mathrm{Mg}_{0.3} \mathrm{O}_{3}$ & 47.3 & $1.0 \% \mathrm{NO}, 3.0 \mathrm{~g} \mathrm{~s} \mathrm{~cm}^{-3}, 850^{\circ} \mathrm{C}$ & [43] \\
\hline $\mathrm{Pt} / \mathrm{SrFe}_{0.7} \mathrm{Mg}_{0.3} \mathrm{O}_{3}$ & 56 & $1.0 \% \mathrm{NO}, 3.0 \mathrm{~g} \mathrm{~s} \mathrm{~cm}^{-3}, 850{ }^{\circ} \mathrm{C}$ & [43] \\
\hline $\mathrm{SrFe}_{0.7} \mathrm{Sn}_{0.3} \mathrm{O}_{3}$ & 42.7 & $1.0 \% \mathrm{NO}, 3.0 \mathrm{~g} \mathrm{~s} \mathrm{~cm}^{-3}, 850{ }^{\circ} \mathrm{C}$ & [43] \\
\hline $\mathrm{SrFe}_{0.7} \mathrm{Ni}_{0.3} \mathrm{O}_{3}$ & 41.6 & $1.0 \% \mathrm{NO}, 3.0 \mathrm{~g} \mathrm{~s} \mathrm{~cm}^{-3}, 850{ }^{\circ} \mathrm{C}$ & [43] \\
\hline $\mathrm{La}_{0.5} \mathrm{Ce}_{0.5} \mathrm{SrNiO} / \mathrm{MgO}$ & 75 & $1.0 \% \mathrm{NO}, 2.4 \mathrm{~g} \mathrm{~s} \mathrm{~cm}^{-3}, 800{ }^{\circ} \mathrm{C}$ & [52] \\
\hline $\mathrm{LaSrMn}_{0.2} \mathrm{Ni}_{0.8} \mathrm{O}_{4+\delta}$ & 85 & $1.0 \% \mathrm{NO}, 1.2 \mathrm{~g} \mathrm{~s} \mathrm{~cm}^{-3}, 850^{\circ} \mathrm{C}$ & [53] \\
\hline
\end{tabular}

\section{Conclusions}

The regeneration of surface oxygen defects in the perovskite catalyst system is an important factor affecting the reaction; the oxygen defects in peroxide-based catalysts are more stable and easily regenerated at high temperatures. However, due to its stability, the initial activity of $\mathrm{NO}$ catalytic decomposition on perovskite-type oxide catalysts is also relatively high. On the other hand, because the formation of perovskite requires a high temperature and long calcination time, while the specific surface area of perovskite oxide is small, it can limit the catalytic ability of the catalyst in catalytic reactions. In general, catalysts require a relatively large specific surface area to effectively adsorb and activate the reactants. Presently, work in this area has focused on changing the composition, structure, and specific surface area of the system to obtain catalysts with high activity for $\mathrm{NO}$ decomposition at low temperatures. Moreover, the $\mathrm{SO}_{2}$ resistance of perovskite-type oxides catalysts needs to be further improved.

Perovskite oxide is a promising NO removal catalyst. Its high activity and low cost make it competitive. Therefore, the search for an efficient perovskite-type catalyst is a subject of great interest. In this paper, the structure, catalytic mechanism and research status 
of perovskite oxides were reviewed, and the developmental direction of perovskite oxides was discussed. The possibility of modifying the catalyst and the method of screening the active catalyst was also indicated.

Author Contributions: Conceptualization, Q.S.; data collection, S.D.; writing, Q.S. and S.D.; figures, S.D.; tables, S.D.; supervision, Q.S.; literature search, S.L.; review and editing, S.L., G.Y. and X.P.; funding acquisition, Q.S., S.L. and G.Y. All authors have read and agreed to the published version of the manuscript.

Funding: This research was funded by THE NATIONAL NATURAL SCIENCE FOUNDATION OF CHINA OF FUNDER, grant number 52001045, CHINA POSTDOCTORAL SCIENCE FOUNDATION OF FUNDER, grant number 2019M651097 and 2019M651094, NATURAL SCIENCE FOUNDATION OF LIAONING PROVINCE OF FUNDER, grant number 2019-ZD-0154 and 2020-HYLH-38, and DA-LIAN CITY INNOVATIVE SUPPORT PROGRAM FOR HIGH-LEVEL TALENTS OF FUNDER, grant number 2019RQ036. The APC was funded by THE FUNDAMENTAL RESEARCH FUNDS FOR THE CENTRAL UNIVERSITIES OF CHINA OF FUNDER, grant number 3132019327.

Acknowledgments: This work was supported by the National Natural Science Foundation of China.

Conflicts of Interest: The authors declare no conflict of interest.

\section{References}

1. Fino, D.; Russo, N.; Saracco, G.; Specchia, V. Catalytic removal of NOx and diesel soot over nanostructured spinel-type oxides. J. Catal. 2006, 242, 38-47. [CrossRef]

2. Reichert, D.; Finke, T.; Atanassova, N.; Bockhorn, H.; Kureti, S. Global kinetic modelling of the reaction of soot with $\mathrm{O}_{2}$ and $\mathrm{NOx}$ on $\mathrm{Fe}_{2} \mathrm{O}_{3}$ catalyst. Appl. Catal. B Environ. 2008, 84, 803-812. [CrossRef]

3. Ishihara, T.; Ando, M.; Sada, K.; Takiishi, K.; Yamada, K.; Nishiguchi, H.; Takita, Y. Direct decomposition of $\mathrm{NO}_{\text {into }} \mathrm{N}_{2}$ and $\mathrm{O}_{2}$ over $\mathrm{La}(\mathrm{Ba}) \mathrm{Mn}(\mathrm{In}) \mathrm{O}_{3}$ perovskite oxide. J. Catal. 2003, 220, 104-114. [CrossRef]

4. Xie, S.; Rosynek, M.P.; Lunsford, J.H. NOx storage on barium-containing three-way catalyst in the presence of $\mathrm{CO}_{2}$. J. Catal. 2001, 72, 59-64.

5. Wise, H.; Frech, M.F. Kinetics of Decomposition of Nitric Oxide at Elevated Temperatures. I. Rate Measurements in a Quartz Vessel. J. Chem. Phys. 1952, 20, 22. [CrossRef]

6. Sun, Q.; Wang, Z.; Wang, D.; Hong, Z.; Zhou, M.; Li, X. A review on the catalytic decomposition of $\mathrm{NO}_{\text {to }} \mathrm{N}_{2}$ and $\mathrm{O}_{2}$ : Catalysts and processes. Catal. Sci. Technol. 2018, 8, 4563-4575. [CrossRef]

7. Zhu, J.; Thomas, A. Perovskite-type mixed oxides as catalytic material for NO removal. Appl. Catal. B Environ. 2009, 92, 225-233. [CrossRef]

8. Carlotto, S.; Natile, M.M.; Glisenti, A.; Vittadini, A. Catalytic Mechanisms of NO Reduction in a CO-NO Atmosphere at Co- and $\mathrm{Cu}$-Doped $\mathrm{SrTiO}_{3}(100)$ Surfaces. J. Phys. Chem. C 2017, 122, 449-454. [CrossRef]

9. Shin, S.; Arakawa, H.; Hatakeyama, Y.; Ogawa, K.; Shimomura, K. Absorption of NO in the lattice of an oxygen-deficient perovskite $\mathrm{SrFeO}_{3-\mathrm{x}}$ and the infrared spectroscopic study of the system $\mathrm{NO}_{-} \mathrm{SrFeO}_{3-\mathrm{x}}$. Mater. Res. Bull. 1979, 14, 633-639. [CrossRef]

10. Teraoka, Y.; Harada, T.; Kagawa, S. Reaction mechanism of direct decomposition of nitric oxide over Co- and Mn-based perovskite-type oxides. J. Chem. Soc. Faraday Trans. 1998, 94, 1887-1891. [CrossRef]

11. Zhu, J.; Xiao, D.; Li, J.; Xie, X.; Yang, X.; Wu, Y. Recycle-New possible mechanism of NO decomposition over perovskite(-like) oxides. J. Mol. Catal. A Chem. 2005, 233, 29-34. [CrossRef]

12. Zhu, J.J.; Yang, X.G.; Xu, X.L. Active site structure of NO decomposition on perovskite(-like) oxides: An investigation from experiment and density functional theory. J. Phys. Chem. C 2007, 111, 1487-1490. [CrossRef]

13. Xu, W.; Yu, Y.; Zhang, C.; He, H. Selective catalytic reduction of $\mathrm{NO}$ by $\mathrm{NH}_{3}$ over a $\mathrm{Ce} / \mathrm{TiO}_{2}$ catalyst. Catal. Commun. 2008, 9 , 1453-1457. [CrossRef]

14. Wang, Z.; Jiang, Z.; Shangguan, W. Simultaneous catalytic removal of NOx and soot particulate over Co-Al mixed oxide catalysts derived from hydrotalcites. Catal. Commun. 2007, 8, 1659-1664. [CrossRef]

15. Xu, P.; Tu, R.; Zhang, S.; Yang, M.; Li, Q.; Goto, T.; Zhang, L. Catalytic Decomposition of Nitric Oxide by $\mathrm{LaCoO}_{3} \mathrm{Nano}$-particles Prepared by Rotary CVD. J. Wuhan Univ. Technol. Sci. Ed. 2018, 33, 368-374. [CrossRef]

16. Imanaka, N.; Masui, T. Advances in direct NOx decomposition catalysts. Appl. Catal. A Gen. 2012, 431, 1-8. [CrossRef]

17. Royer, S.; Duprez, D.; Can, F.; Courtois, X.; Batiot-Dupeyrat, C.; Laassiri, S.; Alamdari, H. ChemInform Abstract: Perovskites as Substitutes of Noble Metals for Heterogeneous Catalysis: Dream or Reality. Am. Chem. Soc. 2014, 114, 10292-10368. [CrossRef]

18. $\mathrm{Hu}, \mathrm{J} . ; \mathrm{Ma}, \mathrm{J} . ;$ Wang, L.; Huang, H. Synthesis and photocatalytic properties of $\mathrm{LaMnO}_{3}$-graphene nanocomposites. J. Alloys Compd. 2014, 583, 539-545. [CrossRef]

19. Yang, P.; Li, N.; Teng, J.J.; Wu, J.; Ma, H. Influence of A-site cation in $\mathrm{La}_{0.7} \mathrm{M}_{0.3} \mathrm{Ni}_{0.7} \mathrm{Fe}_{0.3} \mathrm{O}_{3}(\mathrm{M}=\mathrm{Pr}, \mathrm{Y}, \mathrm{Sr}, \mathrm{Zr}, \mathrm{Ce}) \mathrm{perovskite-type}$ oxides on the catalytic performance. Chem. Res. Appl. 2018, 30, 1979-1985. 
20. Biendicho, J.J.; Shafeie, S.; Frenck, L.; Gavrilova, D.; Böhme, S.; Bettanini, A.M.; Svedlindh, P.; Hull, S.; Zhao, Z.; Istomia, Z.Y.; et al. Synthesis and characterization of perovskite-type $\mathrm{Sr}_{\mathrm{x}} \mathrm{Y}_{1-\mathrm{x}} \mathrm{FeO}_{3-\delta},(0.63 \leq \mathrm{x}<1.0)$ and $\mathrm{Sr}_{0.75} \mathrm{Y}_{0.25} \mathrm{Fe}_{1-\mathrm{y}} \mathrm{MyO}_{3-\delta},(\mathrm{M}=\mathrm{Cr}, \mathrm{Mn}, \mathrm{Ni})$, $(\mathrm{y}=0.2,0.33,0.5)$. J. Solid State Chem. 2013, 200, 30-38.

21. Kabra, S. Perovskite LaxM1-xNi0.8Fe0.2O3catalyst for steam reforming of toluene: Crucial role of alkaline earth metal at low steam condition. Appl. Catal. B Environ. 2014, 148, 231-242.

22. Su, H.-Y.; Sun, K. DFT study of the stability of oxygen vacancy in cubic ABO3 perovskites. J. Mater. Sci. 2014, 50, 1701-1709. [CrossRef]

23. Zhu, J.J.; Yang, X.G.; Xu, X.L. Effect of strontium substitution on the activity of $\mathrm{La}_{2-x} \mathrm{Sr}_{x} \mathrm{NiO}_{4}(\mathrm{x}=0.0-1.2)$ in $\mathrm{NO}$ decomposition. Sci. China Ser. B Chem. 2007, 50, 41-46. [CrossRef]

24. Yasuda, H.; Mizuno, N.; Misono, M. Role of valency of copper in the direct decomposition of nitrogen monoxide over well characterized $\mathrm{La}_{2 x} \mathrm{~A}^{\prime}{ }_{\mathrm{x}} \mathrm{Cu}_{1-\mathrm{y}} \mathrm{B}_{\mathrm{y}}^{\prime} \mathrm{O}_{4}$. Chem. Soc. Chem. Commun. 1990, 16, 1094-1096. [CrossRef]

25. He, F.; Li, X.; Zhao, K.; Huang, Z.; Wei, G.; Li, H. The use of $\mathrm{La}_{1-x} \mathrm{Sr}_{x} \mathrm{FeO}_{3}$ perovskite-type oxides as oxygen carriers in chemical-looping reforming of methane. Fuel 2013, 108, 465-473. [CrossRef]

26. Kirchnerova, J.; Alifanti, M.; Delmon, B. Evidence of phase cooperation in the $\mathrm{LaCoO}_{3}-\mathrm{CeO}_{2}-\mathrm{Co}_{3} \mathrm{O}_{4}$ catalytic system in relation to activity in methane combustion. Appl. Catal. A Gen. 2002, 231, 65-80. [CrossRef]

27. Belessi, V.C.; Costa, C.N.; Baka, T.V. Catalytic behavior of La-Sr-Ce-Fe-O mixed oxidic/perovskitic systems for the NO+CO and $\mathrm{NO}+\mathrm{CH} 4+\mathrm{O} 2$ (lean-NOx) reactions. Catal. Today 2000, 59, 347-363. [CrossRef]

28. Zhao, B.; Wang, R.; Yang, X.X. Simultaneous catalytic removal of NOx and diesel soot particulates over $\mathrm{La}_{1-\mathrm{x}} \mathrm{Ce}_{\mathbf{x}} \mathrm{NiO}_{3}$ perovskite oxide catalysts. Catal. Commun. 2009, 10, 1029-1033. [CrossRef]

29. Shin, S.; Hatakeyama, Y.; Ogawa, K.; Shimomura, K. Catalytic decomposition of NO over brownmillerite-like compounds, $\mathrm{Ca}_{2} \mathrm{Fe}_{2} \mathrm{O}_{5}$ and $\mathrm{Sr}_{2} \mathrm{Fe}_{2} \mathrm{O}_{5}$. Mater. Res. Bull. 1979, 14, 133-136. [CrossRef]

30. Zhu, J.; Zhao, Z.; Xiao, D.; Li, J.; Yang, X.; Wu, Y. CO Oxidation, NO Decomposition, and NO + CO Reduction over Perovskite-like Oxides $\mathrm{La}_{2} \mathrm{CuO}_{4}$ and $\mathrm{La}_{2-x} \mathrm{Sr}_{x} \mathrm{CuO}_{4}$ : An MS-TPD Study. Ind. Eng. Chem. Res. 2005, 44, 4227-4233. [CrossRef]

31. Chen, L.; Niu, X.; Li, Z.; Dong, Y.; Wang, N.; Yuan, F.; Zhu, Y. The effects of $\mathrm{BaO}$ on the catalytic activity of $\mathrm{La}_{1.6} \mathrm{Ba}_{0.4} \mathrm{NiO}_{4}$ in direct decomposition of NO. J. Mol. Catal. A Chem. 2016, 423, 277-284. [CrossRef]

32. Iwakuni, H.; Shinmyou, Y.; Yano, H.; Matsumoto, H.; Ishihara, T. Direct decomposition of $\mathrm{NO}$ into $\mathrm{N}_{2}$ and $\mathrm{O}_{2}$ on $\mathrm{BaMnO}_{3}$-based perovskite oxides. Appl. Catal. B Environ. 2007, 74, 299-306. [CrossRef]

33. Zhang, H.; Li, X.; Hui, Y.; Yu, L.; Xia, Q.; Luo, S.; Yao, C. Development of $\mathrm{La}_{1-x} \mathrm{CexFeO}_{3} /$ attapulgite nanocomposites for photocatalytic reduction of NO at low temperature. J. Mater. Sci. Mater. Electron. 2017, 28, 9371-9377. [CrossRef]

34. Li, X.; Yin, Y.; Yao, C.; Zuo, S.; Lu, X.; Luo, S.; Ni, C. La1-Ce $\mathrm{MnO}_{3}$ /attapulgite nanocomposites as catalysts for $\mathrm{NO}$ reduction with NH3 at low temperature. Particuology 2016, 26, 66-72. [CrossRef]

35. Dong, Y.-H.; Xian, H.; Lv, J.-L.; Liu, C.; Guo, L.; Meng, M.; Tan, Y.-S.; Tsubaki, N.; Li, X.-G. Influence of synthesis conditions on NO oxidation and NOx storage performances of $\mathrm{La}_{0.7} \mathrm{Sr}_{0.3} \mathrm{MnO}_{3}$ perovskite-type catalyst in lean-burn atmospheres. Mater. Chem. Phys. 2014, 143, 578-586. [CrossRef]

36. Gao, L.; Au, C. Studies on the redox behaviour of $\mathrm{La}_{1.867} \mathrm{Th}_{0.100} \mathrm{CuO}_{4}$ and its catalytic performance for NO decomposition. Catal. Lett. 2000, 65, 91-98. [CrossRef]

37. Iwakuni, H.; Shinmyou, Y.; Yano, H.; Goto, K.; Matsumoto, H.; Ishihara, T. Effects of Added $\mathrm{CO}_{2}$ and $\mathrm{H}_{2}$ on the Direct Decomposition of $\mathrm{NO}$ over $\mathrm{BaMnO}_{3}$-Based Perovskite Oxide. Bull. Chem. Soc. Jpn. 2008, 81, 1175-1182. [CrossRef]

38. Teraoka, Y.; Torigoshi, K.; Kagawa, S. Inhibition of NO Decomposition Activity of Perovskite-type Oxides by Coexisting Carbon Dioxide. Bull. Chem. Soc. Jpn. 2001, 74, 1161-1162. [CrossRef]

39. Yokoi, Y.; Uchida, H. Catalytic activity of perovskite-type oxide catalysts for direct decomposition of NO: Correlation between cluster model calculations and temperature-programmed desorption experiments. Catal. Today 1998, 42, 167-174. [CrossRef]

40. Zhao, Z.; Yang, X.; Wu, Y. Comparative study of Nickel-based perovskite-like mixed oxide catalysts for direct decomposition of NO. Appl. Catal. B Environ. 1996, 8, 281-297. [CrossRef]

41. Zhu, Y.; Wangm, D.; Yuan, F.; Zhang, G.; Fu, H. Direct NO decomposition over $\mathrm{La}_{2 \times} \mathrm{Ba}_{x} \mathrm{NiO}_{4}$ catalysts containing BaCO 3 phase. Appl. Catal. B Environ. 2008, 82, 255-263. [CrossRef]

42. Zhu, J.J.; Zhao, Z.; Xiap, D.; Li, J.; Yang, X.; Wu, Y. Effect of valence of copper in $\mathrm{La}_{2-\mathrm{x}} \mathrm{Th}_{\mathrm{x}} \mathrm{CuO}_{4}$ on NO decomposition reaction. Catal. Commun. 2006, 7, 29-32. [CrossRef]

43. Iwakuni, H.; Shinmyou, Y.; Matsumoto, H.; Ishihara, T. Direct Decomposition of NO into $\mathrm{N}_{2}$ and $\mathrm{O}_{2}$ on $\mathrm{SrFe}_{0.7} \mathrm{Mg}_{0.3} \mathrm{O}_{3} \mathrm{Perovskite}$ Oxide. Bull. Chem. Soc. Jpn. 2007, 80, 2039-2046. [CrossRef]

44. Goto, K.; Matsumoto, H.; Ishihara, T. Direct decomposition of NO on Ba/Ba-Y-O catalyst. Top. Catal. 2009, 52, 1776-1780. [CrossRef]

45. Xu, W.; Cai, J.; Zhou, J.; Ou, Y.; Long, W.; You, Z.; Luo, Y. Highly Effective Direct Decomposition of Nitric Oxide by Microwave Catalysis over $\mathrm{BaMeO}_{3}(\mathrm{Me}=\mathrm{Mn}, \mathrm{Co}, \mathrm{Fe})$ Mixed Oxides at Low Temperature under Excess Oxygen. ChemCatChem 2015, 8 , 417-425. [CrossRef]

46. Glisenti, A.; Natile, M.M.; Carlotto, S.; Vittadini, A. Co- and Cu-Doped Titanates: Toward a New Generation of Catalytic Converters. Catal. Lett. 2014, 144, 1466-1471. [CrossRef]

47. Ura, B.; Trawczyński, J.; Zawadzki, M.; Gomez, M.I.; López, A.B.; Suárez, F.L. $\mathrm{Sr}_{1-\mathrm{x}} \mathrm{K}_{\mathrm{x}} \mathrm{TiO}_{3}$ catalysts for diesel soot combustion. Catal. Today 2011, 176, 169-172. [CrossRef] 
48. Zhu, J.J.; Xiao, D.H.; Li, J. Mechanism of NO decomposition on perovskite (-like) catalysts. Chin. Sci. Bull. 2005, 50, 707-710. [CrossRef]

49. Zhu, J.J.; Xiao, D.H.; Li, J.; Yang, X.; Wu, Y. Effect of Ce on NO direct decomposition in the absence/presence of $\mathrm{O}_{2}$ over $\mathrm{La}_{1-\mathrm{x}} \mathrm{Ce}_{\mathrm{x}} \mathrm{SrNiO}_{4}(0 \leq \mathrm{x} \leq$ 0.3). J. Mol. Catal. A Chem. 2005, 234, 99-105. [CrossRef]

50. Zhu, J.; Xiao, D.; Li, J.; Yang, X.; Wei, K. Effect of Ce and $\mathrm{MgO}$ on $\mathrm{NO}$ decomposition over $\mathrm{La}_{1-\mathrm{x}}-\mathrm{Ce}_{\mathrm{x}}-\mathrm{Sr}-\mathrm{Ni}-\mathrm{O} / \mathrm{MgO}$. Catal. Commun. 2006, 7, 432-435. [CrossRef]

51. Zhu, J.J.; Xiao, D.H. Perovskite-like mixed oxides $\left(\mathrm{LaSrMn}_{1-\mathrm{x}} \mathrm{Ni}_{\mathrm{x}} \mathrm{O}_{4+\delta}, 0 \leq \mathrm{x} \leq 1\right)$ as catalyst for catalytic NO decomposition: TPD and TPR Studies. Catal. Lett. 2009, 129, 240-246. [CrossRef]

52. Ma, Z.; Gao, X.; Yuan, X.; Zhang, L.; Zhu, Y.; Li, Z. Simultaneous catalytic removal of NOx and diesel soot particulates over $\mathrm{La}_{2-x} \mathrm{~A}_{x} \mathrm{Ni}_{1-y} \mathrm{ByO}_{4}$ perovskite-type oxides. Catal. Commun. 2011, 12, 817-821. [CrossRef]

53. Gao, L.; Chua, H.T.; Kawi, S. The direct decomposition of $\mathrm{NO}$ over the $\mathrm{La}_{2} \mathrm{CuO}_{4}$ nanofiber catalyst. J. Solid State Chem. 2008, 181, 2804-2807. [CrossRef]

54. Wang, Z.; Li, Z.; Cui, Y.; Chen, T.; Hu, J.; Kawi, S. Highly Efficient NO Decomposition via Dual-Functional Catalytic Perovskite Hollow Fiber Membrane Reactor Coupled with Partial Oxidation of Methane at Medium-Low Temperature. Environ. Sci. Technol. 2019, 53, 9937-9946. [CrossRef] [PubMed]

55. Dhal, G.C.; Dey, S.; Mohan, D. Solution combustion syntheses of perovskite-type catalysts for diesel engine exhaust gas purification. Mater. Today Proc. 2017, 4, 10489-10493. [CrossRef] 